\title{
Translation analysis of subtitle from English into Indonesian in The Raid 2 Movie
}

\author{
Rianto Duta Wicaksono ${ }^{1}$ and Yuli Kuswardani ${ }^{1}$ \\ ${ }^{1}$ English Education Department, Universitas PGRI Madiun, Indonesia
}

\begin{tabular}{|c|c|}
\hline Article Info & ABSTRACT \\
\hline Article history: & \multirow{9}{*}{$\begin{array}{l}\text { Indonesian movies make foreigners interested to watch it. English subtitle is } \\
\text { the solution to make Indonesian movies worldwide. Subtitle's strategies to } \\
\text { make good subtitle is very important to make clear subtitle. The objective of } \\
\text { the research are to identify subtitling strategies subtitle used in translating } \\
\text { The Raid } 2 \text { movie and to describe the subtitling clarity of The Raid } 2 \text { movie's } \\
\text { English subtitle. The research method used is descriptive approach. The data } \\
\text { are required from three source, they are the script of The Raid } 2 \text { movie, the } \\
\text { reader evaluation and the expert evaluation. This research uses } \\
\text { documentation as the technique of collecting data. The researchers use data, } \\
\text { investigator, and theory triangulation to make this research can be trusted. } \\
\text { The results of this research show that: (1) there are } 11 \text { strategies that subtitle } \\
\text { used in translating The Raid } 2 \text { movie; (2) the clarity of subtitle in The Raid } 2 \\
\text { movie is high. The percentage of subtitling clarity from respondents is } 91 \text {, } \\
\text { 02\%. The researchers obtain } 41 \text { subtitles included into lowest score, } 154 \\
\text { subtitles included into medium score, and } 681 \text { subtitles included into high } \\
\text { score. }\end{array}$} \\
\hline Received Jul 12, 2019 & \\
\hline Revised Sep 25, 2019 & \\
\hline Accepted Oct 28, 2019 & \\
\hline & \\
\hline Keywords: & \\
\hline Translation; & \\
\hline Subtitling Strategy; & \\
\hline Clarity. & \\
\hline
\end{tabular}

Copyright (C) 2019 Department of English Teaching. All rights reserved.

\section{Corresponding Author:}

Yuli Kuswardani,

English Education Department, Universitas PGRI Madiun, Indonesia

Jalan Setiabudi No 85 Madiun.

Email: ikuswardaniae@gmail.com

\section{Introduction}

Language is very important for human. People use language as a device of communicating with other people. Communication is very important to interact in society. Without communication, people likely live in the jungle who do not need other people's help. Yule (2010: 20) states, "In a very broad sense, language does serve as a type of communication system that can be observed in a variety of different situations". This statement means that language is what people need to communicate. They use language to interact or communicate with other people and express what the people need or what the people feel based on each situation.

Communication happened between two people or more, but generally they are divided into two important elements. They are sender as the people who give or send the message and receiver as listener or reader. One of problems in communication is the difference between first language and other language. If someone who speaks English as the first language and other participants do not master it, so the communication will be ineffective.

Based on the explanation above, to make communication done well the participants need to transfer English into others or do the same on the contrary. The process of transferring the first language into the second language is called translation. Mounin (in Bassnet, 2002: 24) perceives, "translation as a series of operations of which the starting point and the end product are significations and function within a given culture." It means that translation as the process to transfer idea in first language to others based on main significance. To translate a language, translator needs to comprehend the culture of the original language. Taking example from English and Indonesian, each language has different way to express the sender's idea. Expression of, If I had a dollar for every brain you dont have, I'd have one dollar is example of swear word in English. The sentence shows that sender's culture rather like to use imagery to express the idea indirectly. The sentence in brief has a short meaning that sender assumes that person he or she talks to is not intelligent. 
Different with Indonesian, the sentence will be changed into shorter form that express the message directly. Indonesian people suppose to say tindakan yang kamu lakukan benar-benar bodoh, than express it into imagery sentence like this one jika uang satu rupiah dapat membuatmu tidak mempunyai otak, maka aku punya satu rupiah.

Georgakopoulou (in Cintas and Anderman, 2009: 21) states that interlingual subtitling is a type of language transfer in which the translation, that is the subtitles, do not replace the original Source Text (ST), but rather, both are present in synchrony in the subtitled version. Sentences of the translation result usually appear in the bottom of screen as the result of transfering audiovisual language into a specific language usually national language. Subtitles of a movie appear in the same time of the original language spoken or written. The presence of subtitles make viewers understand what the actors said and the content of foreign movie.

As the global effect, Indonesians at present like watching newest movie from America or Europe at movie theater or at home. Taking example from Hollywood, all of the movies use English and most of them are in demand. For Indonesians who do not master in English, it will be difficult to enjoy the foreign movie without translation. If cartoons usually translated by dubbing technique because the target of viewers are children and teenagers, the others use subtitles because it is cheaper and easy to produce.

Subtitles is not only very helpful for Indonesians to enjoy foreign movies, but also helpful for Indonesian movie advancement. Nowadays, Indonesian movie industries try to enter world box office movies. One of the good results is The Raid movies that produced in two sequels. The Raid 2 movie took place of shooting in Indonesia and starring mostly Indonesian. This movie mostly used Indonesian, so to make it goes international the language in The Raid 2 movie has to be translated into English. Like other action movies, this movie uses subtitle technique to transfer language into English. Based on the explanation above, the researchers observe what and how the subtilting technique used.

\section{Method}

Research Approach and Type

This research uses descriptive qualitative approach because the researchers analyze the form of description such words and sentences. This is a kind of content or document research which analyze document material. Ary et al (2010: 29) state that content research is a research where the researcher analyzes recorded material such as public record, textbooks, letters, films, tapes and other documents. The researchers want to analyze subtitling strategies and clarity of subtitle in The Raid 2 movie. The result of this analysis will be arranged systematically in the form of words and sentences.

Data Source

The researchers use the video and the script of The Raid 2 movie as the primary data. The researchers also use the result of readers and expert evaluations as the secondary data.

\section{Collecting Data Technique}

The researchers apply documentation to take the script and video of The Raid 2 movie in English subtitle, the result of readers and expert evaluations.

Sampling Technique

Sampling technique used by researchers is purposive sampling. The researchers select data which represent the need of research based on certain consideration. The researchers choose only the data that really needed by the researchers with some requirements to support the research. The data of this research is sentences in Indonesian (spoken) and English (written) as the subtitle taken from The Raid 2 movie, the result of readers and expert evaluations..

Analyzing Data Technique

The researchers analize the data using interactive analysis model consists of data reduction, data display, conclusion and verification from Miles and Huberman (1994: 10). The researchers reduce the data from the script of the movie by choosing part of the movie that will be used as the data and select the dialogues used. The data selected from the script and data from the result of expert and the readers evaluations are analyzed and presented in the data display. Tables are used in order to make the analysis is easier to comprehend and interpret. Finally, researchers make a conclusion about the finding.

Data Validity Technique

This research uses data, investigator, and theory triangulation, The researchers gain different data source from video and the script of The Raid 2 movie and the result of readers and expert evaluations. In this research, the researchers decide to use investigator triangulation to check the validity of the data. The researchers ask some experts who have capability in translation scope to identify and analyze the data finding. The researchers also provide some theories supporting the research in order to make the result is trusted and valid. 


\section{Finding and Discussion}

\section{Subtitling Strategies}

The researchers find 11 subtitling strategies used by the subtitler in making subtitle of The Raid 2 movie, they are presented as follows:

1. Using three fullstop symbols to replace the lag conversation in the movie's dialogue.

Example:

SL: Jadi . . .kita balik lagi ke soal ambisi . . . batasan.

TL: So... I guess this bring us back full circle, ambition ... and limitation.

Subtitler recognizes that the use of three fullstops as the symbol of the sentence is not complete. After the word 'so' said by Bejo, there is a space with the next words to be said. This is happened too in the next phrase between words 'ambition' and 'limitation'.

The total subtitle that is identified by the researchers is 876 , but the subtitles that are categorized into subtitle strategies are 51 . The first subtitling strategy has 3 examples. The calculation result of this strategy is $5,88 \%$ of overall subtitle strategy.

2. Translating actor's dialogues into idiomatic expressions based on the context.

Example:

SL: Kita bisa masuk terus salaman atau masuk langsung main kasar.

TL: We could go in smilling or storm in shooting.

In that subtitle there are two phrases which have the same rhyme. The same rhyme is made by word choosing to make a good idiomatic expression. 'Go in smilling and storm in shooting' is the idiomatic translation result of masuk terus salaman and masuk langsung main kasar.

There are 8 examples of this subtitling strategy. The percentage of translating source data into idiomatic expressions in the movie's subtitle is $15,69 \%$ of overall subtitles strategy.

3. Giving additional word or phrase in order to make subtitle has good structural sentence.

Example:

SL: Cuma beberapa bulan.

TL: It will only be a few months.

If the clause cuma beberapa bulan is translated into English it will be 'only be a few months'. In this subtitle, subtitler makes it structurally completed by subject 'it'. The word 'will' as the explanatory that Rama be a spy for a few months in the next, not at present or in the past.

There are 9 examples of this strategy, and the percentage of giving additional word or phrase to make subtitle has good structural sentence in the movie's subtitle is $17,65 \%$ of overall subtitles.

4. Using general terms for Indonesian spesific things in order to make foreign viewers are easier to understand the movie's story.

Example:

SL: Jadi loe preman pasar?

TL: So you're debt collector?

The word preman pasar is an Indonesian term that describes people in the traditional market who have more powerful than other and have many bad habits like asking money to others, eat at the shop without pay and etc. This term is not commonly known internationally, but it almost similar with debt collector's habbit in the western. Subtitler uses 'debt collector' as the translation result of preman pasar because it has nearest definition.

As Gottlieb (in Ghaemi and Benyamin, 2010: 42) states, "expansion is used when the original text requires an explanation because of some cultural nuance not retrievable in the target language." This statement means that translating specific terms in source language into common terms in target language is needed. It can be used to make the reviewers get misunderstanding of the subtitles.

The percentage of using general terms for Indonesian spesific things in the movie's subtitle is $1,96 \%$ of overall subtitles strategy.

5. Using US Dollar currency so that foreigner viewers understand how much value for the money in the story.

Example:

SL: Tapi bulan ini, loe masih kurang bayar lima puluh juta.

TL: But this month, you're short $\$ 5000$. 
Subtitler makes this subtitle in order to make the viewers from other countries understand the movie by reading English subtitle and certain terms. Rupiah as Indonesia's currency is not famously known internationally of its value. So, in the context of money, subtitler uses US Dollars with the value Rp 10.000,- of each Dollar. The percentage of using this strategy is $1,96 \%$ of overall subtitles.

6. Giving additional subtitle in the certain situation like certain sounds and visuals which have specific signs although does not said in the dialogue.

Example:

(GUN COCKS)

Subtitler gives subtitle in parenthesis capitally while a figure in the movie prepared the gun to shoot the other. For some viewers, without this additional subtitle the story is understood because the sound of cocking gun is audible, but its existence is acceptable because it does not disturb the display. The total number in the use of this strategy is 9 subtitles or $17,65 \%$ of overall subtitles strategy.

7. Gives additional swear words to certain subtitles based on the context.

Example:

SL: Dan loe seharusnya masih jauh di bawah sana untuk bisa ketemu gue sekarang disini.

TL: And you should have been fucking steps away from a meeting like this.

This conversation contains of invective word from Bejo to Rama's brother with snapped voice. Subtitler adds 'fucking' word as the expression that Bejo is angry to the man then he says loe seharusnya masih jauh di bawah sana untuk bisa ketemu gue as the invective expression.

This number of the use of this strategy is 9 examples. This strategy takes $17,65 \%$ of overall subtitles strategy.

8. Giving subtitle about actor's name to tells who is not visible speaker in the movie.

Example:

SL: Kamu menghubungi siapa?

TL: BUNAWAR: You called?

When figure of the movie who is talking is not appeared in the screen, subtitler gives sign in the beginning of the sentence. In this scene Bunawar is talking to other peolple but the picture showing Rama, so subtitler writes 'BUNAWAR' before the subtitles as the information that the speaker is the actor but is not appeared in the screen.

There are 2 data of this strategy. As the result, this strategy takes $3,92 \%$ of overall subtitles strategy.

9. Giving additional subtitle as the notification that the dialogue in the scene is not in Indonesia.

Example:

GOTO IN JAPANESE: Do you know of a man goes by the name Bejo?

Subtitler gives English subtitles while the actor (Mr. Goto) is speaking in Japanese in order to keep the story understood. To help viewers recognize the language Mr. Goto used, subtitler writes 'GOTO IN JAPANESE' not 'IN JAPANESE' because the movie displays other actor whereas actually Mr. Goto is speaking. Subtitler does not give Indonesian subtitle because he already writes in English and the target language of this subtitle is English not Indonesian.

There are 3 data of subtitling strategy above. The percentage of this strategy is 5,88\% of overall subtitling strategy.

10. Adjusting subtitle with the culture of target language.

Example:

SL: Mau bapak apa?

TL: What do you want?

In the scene, Rama asks to Bunawar politely so he uses word mau bapak apa? not mau mи ара? In English, the word 'you' is commonly used in the polite or impolite situation. If both source and target languages texts are compared, source language dialogue is more polite than the subtitle. So, subtitler only writes 'What do you want?' not 'What do you want, sir?' because of the different cultural background of those languages.

This strategy has 5 examples. This strategy takes $9,80 \%$ of overall subtitles.

11. Showing two dialogues in once subtitle appearance.

Example: 
SL: Apa-apaan ini?! Tenang. Nggak papa.

TL: What the fuck was that? It's okay. Just calm down.

In the dialogue above the speakers are Rama and Bunawar. Subtitle appeared in the screne when

Rama said apa-apaan ini?! and the camera changes to shoot Bunawar quickly when he said Tenang.

Nggak papa. Subtitler recognizes if the subtitle was separated or appeared when an actor was speaking, the subtitle 'What the fuck was that?!' will not clearly read by viewers.

From the example above, it can be summed up that the percentage of this strategy is $1,96 \%$ of overall subtitles.

Subtitling Clarity

The data in this chapter is about the clarity of readers understanding from the subtitling result. The researchers choose all English subtitles in the movie, but to find out the subtitling clarity some subtitles are not taken. Subtitles of actor's names, yes/no, hello, okay, and expressions of yelling and grunting like 'huh', 'ah', 'shh' which have not meaning are not included as the clarity parameter data.

Respondents or readers of this parameter are people who skilled in English. Those people need to give a check mark in every number based on his/her understanding of the subtitles' meaning. The parameter table is about the clarity scores of subtitling result. It can be seen as table below:

Table 1. The Parameter of Translation Clarity Score.

\begin{tabular}{lccc}
\hline \multicolumn{1}{c}{ Qualitative Parameter } & Score & $\begin{array}{c}\text { Clarity } \\
\text { Categories }\end{array}$ \\
\hline $\begin{array}{l}\text { Translation is difficult or even very difficult to be } \\
\text { understood by the reader. }\end{array}$ & 1 & Low clarity \\
\hline $\begin{array}{l}\text { Generally reader understand the translation, but there are } \\
\text { phrases that must be read more than once to get it. }\end{array}$ & 2 & Medium clarity \\
\hline $\begin{array}{l}\text { Words, technichal terms, phrases, clauses, and even } \\
\text { sentences in the translation can be understood easily by the } \\
\text { reader. }\end{array}$ & 3 & High clarity
\end{tabular}

To answer the second problem statement, the researchers need to get respondents in order to complete the data. The researchers choose 4 people who already graduated from English Department Ikip Pgri Madiun and all of them have TOEFL score more than 500. Every respondent gives more than 220 clarity scores in the data. After they give their clarity score, the data are presented in the table below:

Table 2. Result of Clarity Scores Taken from 4 Respondents

\begin{tabular}{|c|c|c|c|c|c|}
\hline \multirow[t]{2}{*}{ Page } & \multirow[t]{2}{*}{ Data Numbers } & \multicolumn{3}{|c|}{$\begin{array}{c}\text { Clarity Score Responds per } \\
\text { Page }\end{array}$} & \multirow{2}{*}{$\begin{array}{c}\text { Total of C. S. per } \\
\text { Page }\end{array}$} \\
\hline & & 1 & 2 & 3 & \\
\hline 1 & $1-34$ & 0 & 7 & 27 & 95 \\
\hline 2 & $35-66$ & 2 & 8 & 22 & 84 \\
\hline 3 & $67-101$ & 0 & 7 & 28 & 98 \\
\hline 4 & $102-139$ & 4 & 3 & 31 & 103 \\
\hline 5 & $140-174$ & 3 & 12 & 20 & 87 \\
\hline 6 & $175-208$ & 3 & 5 & 26 & 91 \\
\hline 7 & $209-239$ & 1 & 7 & 23 & 84 \\
\hline 8 & $240-275$ & 1 & 4 & 31 & 102 \\
\hline 9 & $276-311$ & 2 & 7 & 27 & 97 \\
\hline 10 & $312-346$ & 2 & 8 & 25 & 93 \\
\hline 11 & $347-379$ & 3 & 10 & 20 & 83 \\
\hline 12 & $380-414$ & 2 & 8 & 25 & 93 \\
\hline 13 & $415-447$ & 0 & 2 & 31 & 97 \\
\hline 14 & $448-484$ & 3 & 5 & 29 & 100 \\
\hline 15 & $485-520$ & 2 & 6 & 28 & 98 \\
\hline 16 & $521-556$ & 1 & 4 & 31 & 102 \\
\hline 17 & $557-587$ & 1 & 5 & 25 & 86 \\
\hline 18 & $588-619$ & 1 & 8 & 23 & 86 \\
\hline
\end{tabular}

Translation Analysis of Subtitle, Rianto Duta Wicaksono 


\begin{tabular}{cccccc}
19 & $620-652$ & 2 & 2 & 29 & 93 \\
\hline 20 & $653-688$ & 1 & 5 & 30 & 101 \\
\hline 21 & $689-725$ & 0 & 7 & 30 & 104 \\
\hline 22 & $726-757$ & 2 & 3 & 27 & 89 \\
\hline 23 & $758-795$ & 2 & 5 & 31 & 105 \\
\hline 24 & $796-834$ & 2 & 11 & 26 & 102 \\
\hline 25 & $835-872$ & 1 & 4 & 33 & 108 \\
\hline 26 & $873-876$ & 0 & 1 & 3 & 11 \\
\hline & Total & $\mathbf{4 1}$ & $\mathbf{1 5 4}$ & $\mathbf{6 8 1}$ & \\
\hline
\end{tabular}

Total of Clarity Score

2392

Based on the data above, the researchers find subtitling clarity percentage shown in the table below: Table 3. Subtitling Clarity Percentage

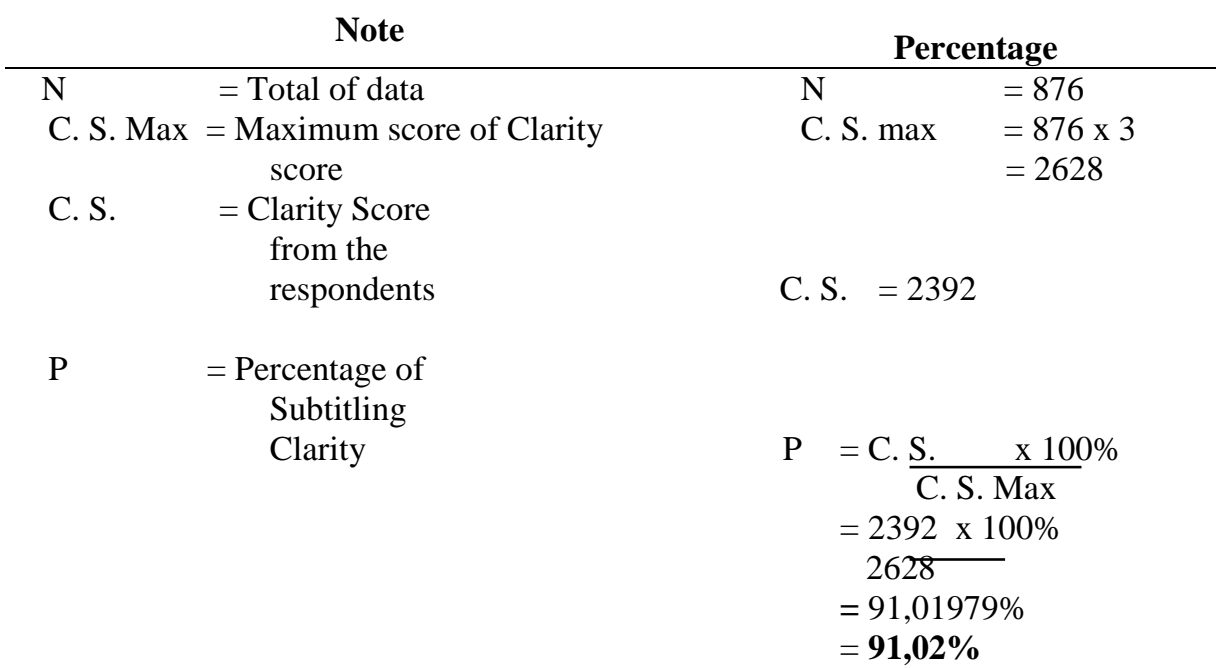

From the overall data from those 4 respondents, the researchers obtain 41 subtitles which included into lowest score. This is caused by the difficulty of respondents to find the meaning or they did not know the words, phrases and terms before. While in the medium clarity, there are 154 subtitles that make respondents have to read more than once to get the meaning. The last is highest clarity which has 681 subtitles included in it.

From the short interview that the researchers had done, respondents give 1 score to the subtitles because his/her unknown of certain specific terms. In the next, they need to read it more than once and give 2 scores because the sentences or subtitles are long. Beside it, they also need a few times to remember what the sentence's meaning. In highest clarity, respondents be able to find the subtitle's meaning easily.

From the low, medium, and high clarity above, the researchers get the total clarity score is 2392 from 876 subtitles (see table 2). The total clarity score is gotten by sum all scores in every page. The maximum score from 876 subtitles is 2628 which come from 876 multiplied by 3. To make this study clear, the researchers need to find the percentage of subtitling clarity from those scores.

The overall clarity score is 2392 divided by overall maximum clarity score that is 2628 then multiplied by $100 \%$. In the result, the percentage of overall clarity score of The Raid 2 movie's English subtitle is $91,02 \%$ as seen in the table 3 above. It means that this subtitle has high possibility to make the foreigner viewers understand the movie's story. 


\section{Conclusion}

There are 11 strategies that subtitler uses in translating from Indonesian into English. Those strategies are: (1) using three fullstop symbols; (2) translating actor's dialogues into idiomatic expressions; (3) giving additional word or phrase to makes subtitle has good structural sentence; (4) using general terms for Indonesian spesific things; (5) using US Dollar currency; (6) giving additional subtitle in the certain situation; (7) giving additional swear words to certain subtitles based on the context; (8) giving subtitle about actor's for not visible speaker; (9) giving additional subtitle if the dialogue in the scene is not in Indonesian; (10) adjusting subtitle with the culture of target language; (11) showing two dialogues in once subtitle appearance. From respondents evaluations it is known that the percentage of subtitling clarity is $91,02 \%$. The researchers obtain 41 subtitles included into lowest score, 154 subtitles included into medium score, and 681 subtitles included into high score.

To know strengths and weaknesses of Indonesian movie's subtitlers, it is important to analyze movie's subtitles. The essential thing to make movie's subtitles to certain language is understanding the culture and habit of the people in the target language. The clarity of subtitle is very important too.

\section{References}

Ary, D. et al. 2010. Introduction to Research in Education Eight Edition. USA: Wadsworth, Cengage Learnin.

Bassnett, S. (2002). Translation Studies. London: Routledge Taylor \& Francis Group.

Bell, Roger T. 1991. Translation and Translating: Theory and Practice. New York: Longman

Carey, S. (2010). Translation Types and Repetition: A Finnish Version of Psalm 49 Evaluated. Unpublished dissertation. Birmingham: Department of English University of Birmingham.

Cintas, J. D. and Anderman, G. (2009). Audiovisual Translation: Language Transfer on Screen. UK: Palgrave Macmillan.

Ghaemi, F and Benyamin, J. (2010). Strategies Used in the Translation of Interlingual Subtitling. Azad: Islamic Azad University.

Miles, M. B and Huberman, A M. (1994). Qualitative Data Analysis. California: Sage Publication.

Silalahi, Roswita. (2009). DampakTeknik, Metode, danIdeologiPenerjemahanTeks Medical- Surgical Nursing dalamBahasa Indonesia. Sumatera Utara: SekolahPascasarjanaUniversitas Sumatera Utara.

Yule, G. (2010). The Study of Language. USA: Cambridge University Press. 